\title{
An Appraisal of Sexual Behaviors, STI/HIV Prevalence, and HIV Prevention Programs among Truckers in India: A Critical Literature Review
}

\author{
Damodar Sahu1, Arvind Pandey , Ram Manohar Mishra ${ }^{2 *}$, Niranjan Saggurti², \\ Shekhar Setu ${ }^{3}$, Indra Raj Singh ${ }^{4}$ \\ ${ }^{1}$ National Institute of Medical Statistics, New Delhi, India \\ ${ }^{2}$ Population Council, New Delhi, India \\ ${ }^{3}$ Family Health International, New Delhi, India \\ ${ }^{4}$ Transport Corporation of India Foundation, Gurgaon, India \\ Email: ${ }^{*}$ rammanohar7@yahoo.co.in
}

Received 27 March 2014; revised 27 April 2014; accepted 10 May 2014

Copyright (C) 2014 by authors and Scientific Research Publishing Inc.

This work is licensed under the Creative Commons Attribution International License (CC BY). http://creativecommons.org/licenses/by/4.0/

(c) (i) Open Access

\section{Abstract}

Background: A systematic review portraying the changing pattern of sexual behaviors, STI and HIV prevalence and key strategies curb HIV and STI among truckers in India is lacking. This paper therefore aims to present a chronological review of literature regarding sexual behaviors, STI/HIV prevalence, and various HIV prevention programs implemented among truckers in India. Methodology: Published and unpublished studies (1990-2011) were identified through electronic databases, and hand searching. Results: Most studies on sexual behaviors and STI/HIV prevalence among truckers focused only on drivers and ignored their helpers. Evidences suggest that consistent condom use by truckers with both paid and non-paid female partners has increased during the past decade. Many recent studies suggest that the HIV prevalence among truckers is about $2 \%$ and it has been declining slowly during the past decade. The HIV prevention programs among truckers which started with the aim of raising awareness about HIV during early 1990s, have grown multi-folds to encompass not only the standard strategies like mid-media events, interpersonal counselling and STI care for HIV prevention, but also innovations such as the use of business franchisee models, and integrated research and evidence based planning in the program. The possibilities of using new approaches such as male circumcision and the use of pre-exposure prophylaxes are underway. Conclusion: More studies are needed to explore helpers' vulnerabilities to HIV. Very few studies have attempted to examine the impact of large-scale prevention programs

\footnotetext{
${ }^{*}$ Corresponding author.
} 
among truckers. Efforts are required to examine the impact of different components of such programs to guide the HIV prevention efforts among truckers in India.

\title{
Keywords
}

\author{
Truckers, Sexual Behavior, HIV, Prevention Programs, India
}

\section{Introduction}

Truck drivers and their helpers (hereafter referred to as truckers) are considered to be at high risk of acquiring human immunodeficiency virus (HIV) and sexually transmitted infections (STIs) in many parts of the world [1]-[7]. Truckers' engagement in high risk sexual behaviors, such as sex with multiple sexual partners is largely attributed to their high mobility and absence from their families for extended periods [4] [5] [7] [8]. Truckers are also nationally mobile and hence they have the potential to expand the geographic spread of HIV by linking the epidemic from relatively higher-prevalence areas to lower-prevalence areas of any country [5] [7]. For these reasons, HIV prevention programs across the world have considered truckers as an important bridge group to work with for slowing the spread of HIV into the general population [7] [9]-[13].

India is estimated to have about two to two and half million long-distance truckers [14]. Several studies undertaken in different parts of the country during the past decade have confirmed high-risk sexual behaviors [15]-[20] and high prevalence of STIs (2\% - 14\%) [16] [17] [19] and HIV (2\% - 16\%) [16]-[19] among truckers in India. Due to high-risk sexual behaviors, increased STI/HIV prevalence and ability to spread infections to new geographic areas, truckers have been one of the key target populations in the country's national response to HIV/AIDS since 1996 under National AIDS Control Program II and III [14] [21] [22].

Even though several studies have attempted to describe sexual behaviors and its determinants among truckers in the country, a systematic review portraying the changing pattern of sexual behaviors, STI and HIV prevalence and key strategies to curb HIV and STI among truckers in India is lacking. Such information, if available, is critical for understanding the complex dimensions of sexual behaviors of truckers and also in drawing inputs for initiating and scaling up the HIV prevention strategies among mobile-populations like truckers in India and beyond. Hence, this paper aims to present a chronological review of literature regarding sexual behaviors, STI/ HIV prevalence, and various HIV prevention programs implemented among truckers in India. It also identifies and highlights research gaps and their program implications.

\section{Methodology}

Peer-reviewed articles and reports were identified through a systematic search of online databases including PubMed, Web of Sciences, CrossRef, HIV and AIDS data hub, HIV/AIDS surveillance database of U.S. Census Bureau, Cochrane Review Group on HIV/AIDS, The AIDS Education Global Information System (AGEiS), and Google Scholar. Bibliographies of identified articles were hand searched. Documents and reports available on the websites of National AIDS Control Organization, and other research and program implementation organizations working in the field of HIV prevention in India were researched. We also searched for the abstracts presented in the national and international conferences wherever they were available online. A time-frame of 19902011 was used for the search to better describe the changing pattern of sexual behaviors, STI/HIV and strategies of HIV prevention programs among truckers in India. The articles, reports, presentations, and abstracts with the key words such as "sexual behavior", "prevalence of HIV/STI", "HIV intervention programs", or "HIV prevention", among truckers in India were included in the review.

\section{Results}

A total of 50 relevant literatures about sexual behaviors and STI/HIV prevalence were found (peer reviewed papers: 28; reports: 08; and abstracts presented in conferences: 14). Of these, 38 had information only on sexual behaviors while 12 had information on both sexual behaviors and STI/HIV prevalence. A total of 28 studies were found which described interventions among truckers in India (peer reviewed papers: 8; reports: 10; abstracts presented in conferences: 10). 


\subsection{Sexual Behaviors and Prevalence of STI/HIV among Truckers in India}

Table 1 summarizes the trend in key indicators of sexual behaviors and STI/HIV prevalence among tuckers in India during 1990-2011. Studies conducted during early 1990s reported that about 63\% to $87 \%$ of the truckers reported a history of multiple sex partners including FSWs [23]-[27], and consistent condom use was poor (0\% to $11 \%$ ) in such relationships [23]-[25]. Similar results in terms of history of multiple sex partners including FSWs (80\% - 95\%) [28]-[30] and consistent condom use (2\% - 14\%) [28] [30] were observed in studies undertaken towards the end of 1990s. During this period, studies focusing on sexual behaviors attempted to explore mainly the history of multiple sex partners which is a measure of cumulative risk, and did not stress much on measuring sexual behaviors in recent past [23] [24] [27]-[29]. An exception was a large-scale survey among truckers in 2000 which concluded that nearly one-third of the truckers had sex with FSWs in the past one year preceding the survey [31].

Table 1. An overview of selected studies on sexual behavior and prevalence of STI and HIV among truckers in India, 19902011.

\begin{tabular}{|c|c|c|c|c|c|}
\hline Participants & $\begin{array}{l}\text { Study } \\
\text { year/ } \\
\text { period }\end{array}$ & Study design and methods & $\begin{array}{c}\text { Relevant findings in context of } \\
\text { sexual behavior }\end{array}$ & $\begin{array}{l}\text { Relevant findings } \\
\text { in context of } \\
\text { STI/HIV prevalence }\end{array}$ & Reference \\
\hline Truck drivers & 1992 & $\begin{array}{l}\text { Behavioral survey of } 200 \\
\text { truck drivers in Delhi; } \\
\text { A total of } 302 \text { truck drivers } \\
\text { were tested for HIV. }\end{array}$ & $\begin{array}{l}\text { About } 78 \% \text { of the respondents reported ever } \\
\text { having sex with non-regular female partners } \\
\text { (defined as any female other than wife or steady } \\
\text { sexual partner of the respondent). The life-time } \\
\text { exposure to FSWs was reported as } 62 \% \text {. } \\
5 \% \text { reported ever having sex with } \\
\text { men/transgender }\end{array}$ & HIV: $1.0 \%$ & [27] \\
\hline $\begin{array}{l}\text { Truck drivers } \\
\text { and helpers }\end{array}$ & 1992 & $\begin{array}{l}\text { Behavioral survey of } 210 \\
\text { drivers and } 210 \text { helpers at } \\
\text { major transshipment } \\
\text { location in Indore, } \\
\text { Madhya Pradesh. }\end{array}$ & $\begin{array}{l}\text { About } 63 \% \text { of the truckers (drivers: } 83 \% \text { of the } \\
\text { helpers: } 44 \% \text { ) reported ever having sex with } \\
\text { FSWs and females other than their wives. } \\
\text { Consistent condom use in such relationships } \\
\text { was } 1 \% \text {. }\end{array}$ & Not available. & [23] \\
\hline Truck drivers & 1992 & $\begin{array}{l}\text { Behavioral survey of } 506 \\
\text { truck drivers recruited at a } \\
\text { check post in } \\
\text { Beltola-Basistha area of } \\
\text { Assam. }\end{array}$ & $\begin{array}{l}82 \% \text { of the respondents reported ever having sex } \\
\text { with FSWs. } \\
\text { None of the respondents admitted using condom } \\
\text { consistently with FSWs. } \\
\text { About } 15 \% \text { reported ever having sex with men/ } \\
\text { transgender. }\end{array}$ & Not available. & [25] \\
\hline Truck drivers & 1994 & $\begin{array}{l}\text { Behavioral survey of } 5709 \\
\text { consecutive truck drivers } \\
\text { who consented to take part } \\
\text { in the study while passing } \\
\text { through a check post at the } \\
\text { Andhra Pradesh-Orissa } \\
\text { border in the Srikakulam, } \\
\text { Andhra Pradesh. }\end{array}$ & $\begin{array}{l}87 \% \text { of the participants reported ever having sex } \\
\text { with non-regular female partners (defined as any } \\
\text { female other than wife or steady sexual partner } \\
\text { of the respondent). Information on type of } \\
\text { partners was not available. } \\
\text { Condom use with non-regular female sexual } \\
\text { partners was about } 11 \% \text {. }\end{array}$ & Not available. & [24] \\
\hline Truck drivers & 1998 & $\begin{array}{l}\text { Behavioral survey of } 153 \\
\text { truck drivers recruited from } \\
\text { (road side hotels) along } \\
\text { different highways in } \\
\text { Rajasthan. }\end{array}$ & $\begin{array}{l}80 \% \text { of truck drivers reported ever having sex } \\
\text { with FSWs. } \\
\text { Consistent condom use with FSWs was about } \\
14 \% \text {. }\end{array}$ & Not available. & [28] \\
\hline Truck drivers & 1998 & $\begin{array}{l}\text { Behavioral interview of } \\
300 \text { drivers recruited from } \\
\text { variety of locations } \\
\text { including brokers' offices, } \\
\text { workshops, and loading/ } \\
\text { unloading stations in } \\
\text { Chennai, Tamil Nadu. }\end{array}$ & $\begin{array}{l}\text { About } 95 \% \text { of the respondent reported ever } \\
\text { having had sex with females other than their } \\
\text { wives. } \\
\text { Nearly three-fourth ( } 75 \% \text { ) reported ever having } \\
\text { had sex with FSWs. } \\
\text { Consistent condom use was about } 2 \% \text {. }\end{array}$ & Not available. & [30] \\
\hline
\end{tabular}




\section{Continued}

\begin{tabular}{|c|c|c|c|c|c|}
\hline $\begin{array}{l}\text { Truck drivers } \\
\text { and their } \\
\text { helpers }\end{array}$ & $1998-2000$ & $\begin{array}{l}\text { Behavioral interview and } \\
\text { diagnosis of STIs among } \\
53 \text { drivers and helpers from } \\
\text { a highway STD clinic in } \\
\text { South India. } \\
\text { All participants were tested } \\
\text { for HIV }\end{array}$ & $\begin{array}{l}\text { About } 90 \% \text { of the respondents had a history of } \\
\text { multiple sex partners and } 65 \% \text { reported ever } \\
\text { having sex with FSWs. } \\
\text { Results were not available separately for drivers } \\
\text { and helpers. }\end{array}$ & HIV: $56.8 \%$ & [29] \\
\hline $\begin{array}{l}\text { Truck drivers } \\
\text { and their } \\
\text { helpers }\end{array}$ & 2000 & $\begin{array}{l}\text { Behavioral interview and } \\
\text { diagnosis of STIs and HIV } \\
\text { among } 4811 \text { drivers and } \\
1200 \text { helpers) recruited } \\
\text { from truckers' halt points } \\
\text { on major national } \\
\text { highways. }\end{array}$ & $\begin{array}{l}\text { About } 34 \% \text { drivers and } 30 \% \text { helpers reported } \\
\text { having sex with FSWs in past } 12 \text { months. } \\
\text { Consistent condom use in sex with FSWs was } \\
\text { reported by } 43 \% \text { of the drivers and } 29 \% \text { of the } \\
\text { helpers. }\end{array}$ & & [31] \\
\hline $\begin{array}{l}\text { Truck drivers } \\
\text { and their } \\
\text { helpers }\end{array}$ & 2000 & $\begin{array}{l}\text { Behavioral interview and } \\
\text { diagnosis of STIs and HIV } \\
\text { among } 335 \text { truckers ( } 211 \\
\text { drivers and } 124 \text { helpers) } \\
\text { recruited from truckers' } \\
\text { stop in Kolkata, West } \\
\text { Bengal. Participants were } \\
\text { tested for HIV, syphilis, } \\
\text { gonorrhea, genital } \\
\text { chlamydial infection, } \\
\text { and Hepatitis B. }\end{array}$ & $\begin{array}{l}\text { About } 28 \% \text { of the respondents reported having } \\
\text { sex with FSWs in past } 12 \text { months. } \\
\text { Consistent condom use in sex with FSWs was } \\
\text { reported as } 8 \% \text {. } \\
\text { Results were not available separately for drivers } \\
\text { and helpers. }\end{array}$ & $\begin{array}{l}\text { HIV: } 3.0 \% \\
\text { Syphilis: } 6.3 \% \\
\text { Gonorrhea: } 1.8 \% \\
\text { Genital clamydial } \\
\text { infection: } 1.2 \% \\
\text { Hepatitis B: } 6.3 \%\end{array}$ & [43] \\
\hline $\begin{array}{l}\text { Truck drivers } \\
\text { and their } \\
\text { helpers }\end{array}$ & $1999-2001$ & $\begin{array}{l}\text { Behavioral interview about } \\
\text { sexual behaviors and } \\
\text { diagnosis of STIs among } \\
\text { drivers and helpers from a } \\
\text { highway STD clinic in } \\
\text { Pondicherry, Tamil Nadu. } \\
\text { All participants were tested } \\
\text { for HIV, Hepatitis B virus } \\
\text { infection, and syphilis. }\end{array}$ & $\begin{array}{l}\text { About two-third (67\%) truckers reported } \\
\text { contacts with FSWs in their life-time. } \\
\text { Vaginal sex was the predominant risk in all } \\
\text { participants followed by oral sex ( } 4 \% \text { ), and } \\
\text { anal sex (1\%). } \\
\text { Consistent condom use with FSWs (defined as } \\
\text { use of condom in every sexual encounter) was } \\
\text { about } 16 \% \text {. } \\
\text { About } 1 \% \text { reported having sex with men. } \\
\text { Results were not available separately for drivers } \\
\text { and helpers. }\end{array}$ & $\begin{array}{l}\text { HIV: } 15.9 \% \\
\text { Syphilis: } 13.9 \% \\
\text { Hepatitis B: } 21.2 \%\end{array}$ & [19] \\
\hline Truck drivers & 2004 & $\begin{array}{l}\text { Behavioral interviews of } \\
283 \text { long-distance truck } \\
\text { drivers recruited from a } \\
\text { group of Dhabas (road } \\
\text { side hotels) in Pune, } \\
\text { Maharashtra. }\end{array}$ & $\begin{array}{l}\text { About } 57 \% \text { respondents reported to ever had } \\
\text { having sex with FSWs. } \\
\text { Consistent condom use with FSWs (defined as } \\
\text { use of condom in every sexual encounter) was } \\
\text { about } 7 \% \text {. }\end{array}$ & & [15] \\
\hline $\begin{array}{l}\text { Truck drivers } \\
\text { and their } \\
\text { helpers }\end{array}$ & 2004 & $\begin{array}{l}\text { A behavioral and biological } \\
\text { survey among } 301 \\
\text { long-distance truck drivers } \\
\text { and their helpers recruited } \\
\text { from different transport } \\
\text { workers' stops on the } \\
\text { Siliguri-Guwahati national } \\
\text { highway. Participants were } \\
\text { tested for HIV, hepatitis B } \\
\text { virus, and syphilis. }\end{array}$ & $\begin{array}{l}\text { About } 67 \% \text { reported having sex with FSWs in } \\
\text { their lifetime. } \\
\text { The condom use rate was reported as } 58 \% \text {. }\end{array}$ & $\begin{array}{l}\text { HIV: } 2.3 \% \\
\text { Syphilis: } 6.3 \% \\
\text { Hepatitis B: } 3.7 \%\end{array}$ & [32] \\
\hline Truck drivers & 2006 & $\begin{array}{l}\text { Behavioral interviews of } \\
300 \text { truck drivers recruited } \\
\text { from a truck terminal in } \\
\text { Mumbai, Maharashtra. }\end{array}$ & $\begin{array}{l}\text { About } 36 \% \text { of the respondents reported regular } \\
\text { visits to FSWs. } \\
\text { Consistent condom use with FSWs was about } \\
53 \% \text {. }\end{array}$ & Not Available. & [34] \\
\hline
\end{tabular}




\section{Continued}

\begin{tabular}{|c|c|c|c|c|c|}
\hline Truck drivers & 2007 & $\begin{array}{l}\text { A behavioral and biological } \\
\text { survey among } 2066 \\
\text { long-distance truck drivers } \\
\text { recruited from seven } \\
\text { transshipment locations in } \\
\text { Delhi, Ghaziabad, Kolkata, } \\
\text { Mumbai, Bangalore, } \\
\text { Ahmadabad, and Kandla. } \\
\text { Participants were } \\
\text { interviewed about their } \\
\text { sexual behavior and tested } \\
\text { for HIV, syphilis, Neisseria } \\
\text { gonorrhea and Chlamydia } \\
\text { trachomatis. }\end{array}$ & $\begin{array}{l}\text { Nearly one-third ( } 31 \% \text { ) reported having sex with } \\
\text { FSWs in past one year. The consistent condom } \\
\text { use in past one year with such partners was } \\
\text { reported as } 67 \% \text {. } \\
\text { One-fifth ( } 20 \% \text { ) of the respondents reported } \\
\text { having sex with casual non-paid female partners } \\
\text { in past one year. } \\
\text { The consistent condom use with such partners in } \\
\text { past one year was about } 18 \% \text {. } \\
\text { About } 2 \% \text { reported having sex with } \\
\text { men/transgender in past one year and consistent } \\
\text { condom use with such partners was reported as } \\
30 \% \text {. }\end{array}$ & $\begin{array}{l}\text { HIV: } 4.6 \% \\
\text { Syphilis: } 2.7 \% \\
\text { Neisseria } \\
\text { gonorrhea: } 0.2 \% \\
\text { Chlamydia } \\
\text { trachomatis: } 0.3 \%\end{array}$ & {$[16]$} \\
\hline Truck drivers & 2007 & $\begin{array}{l}\text { Behavioral survey of } 400 \\
\text { long-distance truck drivers } \\
\text { recruited from highways } \\
\text { connecting Punjab to Uttar } \\
\text { Pradesh, Bihar and West } \\
\text { Bengal. }\end{array}$ & $\begin{array}{l}\text { About } 57 \% \text { of the respondents reported } \\
\text { relationships with multiple sexual partners. } \\
\text { Nearly one-third (33\%) reported having sex } \\
\text { with FSWs. } \\
\text { About } 64 \% \text { reported using condom consistently } \\
\text { with FSWs. }\end{array}$ & Not Available. & {$[20]$} \\
\hline $\begin{array}{c}\text { Truck drivers } \\
\text { and their } \\
\text { helpers }\end{array}$ & 2008-2009 & $\begin{array}{l}\text { Four rounds of behavioral } \\
\text { surveys of approximately } \\
1400 \text { long-distance truckers } \\
\text { in each round recruited } \\
\text { from seven transshipment } \\
\text { locations in the country. }\end{array}$ & $\begin{array}{l}\text { About } 40 \% \text { reported having sex with FSWs in } \\
\text { past } 12 \text { months. Consistent condom use with } \\
\text { FSWs was about } 73 \% \text {. } \\
\text { About } 23 \% \text { reported having sex with casual } \\
\text { female sexual partners in past } 12 \text { months and } \\
\text { consistent condom use with such partners was } \\
\text { about } 39 \% \text {. } \\
\text { About } 10 \% \text { reported to have anal sex in past } \\
12 \text { months with men/ women (irrespective of } \\
\text { partners). The consistent condom use among } \\
\text { such relationships was about } 62 \% \text {. }\end{array}$ & Not Available. & [36] \\
\hline Truck drivers & 2009-10 & $\begin{array}{l}\text { A behavioral and biological } \\
\text { survey among } 2085 \\
\text { long-distance truck drivers } \\
\text { recruited from six } \\
\text { transshipment locations in } \\
\text { the country. Participants } \\
\text { were interviewed about } \\
\text { their sexual behavior and } \\
\text { tested for HIV, syphilis, } \\
\text { Neisseria gonorrhea and } \\
\text { Chlamydia trachomatis. }\end{array}$ & $\begin{array}{l}\text { Nearly one-fourth ( } 24 \% \text { ) reported having sex } \\
\text { with FSWs in past one year. The consistent } \\
\text { condom use with such partners was reported as } \\
75 \% \text {. } \\
\text { Nearly one-fifth ( } 21 \% \text { ) reported having sex with } \\
\text { casual non-paid female partners in past one year. } \\
\text { The } \\
\text { Consistent condom use with such partners in } \\
\text { past one year was about } 37 \% \text {. }\end{array}$ & $\begin{array}{l}\text { HIV: } 2.5 \% \\
\text { Syphilis: } 1.7 \% \\
\text { Neisseria } \\
\text { gonorrhea: } 0.1 \% \\
\text { Chlamydia } \\
\text { trachomatis: } 0.1 \%\end{array}$ & [17] \\
\hline
\end{tabular}

FSWs: Female Sex Workers; HIV: Human immunodeficiency virus; STI: Sexually transmitted infections.

Truckers' life-time exposure to FSWs and other non-regular sex partners continued to be high in studies conducted after 2000 although it started showing a sign of declining trend. Studies conducted during 2000-2005 found that about 57\% - 67\% of the truckers ever had sex with FSWs [15] [19] [32]. The consistent condom use with FSWs as observed in these studies showed a wide range from less than 20\% [15] [19] to about 58\% [32]. More recent studies conducted during 2006-2011 suggest that about half of the truckers ever had sex with FSWs [20] [33] [34] and nearly one-third to two-fifth visited FSWs in the past one year preceding the study period [16] [17] [20] [35] [36]. Recent studies show that consistent condom use by truckers with FSWs ranged from 53\% [34] to nearly 75\% [16] [17] [33] [36]. Only few studies investigated about places of sex with FSWs and the most common places were reported to be dhaba (road side eateries) $(13 \%-53 \%)$, bushes/in the field (39\% 84\%), and at the trucks' halt-points (15\% - 75\%) [33] [36] [37].

Only recent studies conducted after 2005 collected information on sexual behaviors with non-paid female partners who are defined as females whom truckers were not married and did not pay in cash for sex [16] [17] [36] [37]. These studies report that about one-fifth of the truckers have sexual relationships with non-paid female partners [16] [17] [33] [36] [37]. The consistent condom use in such sexual encounters was found to have 
increased from about 18\% in 2006 to about 39\% in 2009-10 [16] [17] [36]. Very few studies collected information on truckers' sexual relationships with men/transgender. Studies during early 1990s found that about $5 \%$ to $15 \%$ of the truckers ever had sex with men/transgender [25] [27] whereas this percentage was found to be about $4 \%-8 \%$ in recent two rounds of large-scale surveys among truck drivers [33]. Although, relatively fewer (1\% 2\%) truckers reported having sex with men/transgender within past 12 months preceding the study period [16] [18] [19], recent studies have found that about $10 \%$ of the truckers reported having anal sex with individuals without specifying the gender of the sexual partner [33] [36]. Truckers commonly indicated that "lack of availability of females for sex" or "high-risk of HIV from sex with women" motivated them to have sex with men and transgender [38] [39].

Compared to studies to explore sexual behaviors of truckers, fewer studies captured information STI/HIV prevalence among truckers in India [16]-[19] [26] [27] [29] [40]-[43]. A study conducted in 1992 in Delhi found that HIV prevalence among truckers was about 1\% [27]. This was followed by studies conducted during mid of 1990s in many parts of the country which found high HIV prevalence ranging from about $5 \%$ to $8 \%$ among truckers [40]-[42]. Studies conducted after 2000 found the HIV prevalence in the range of $2 \%$ to $5 \%$ among truckers [16]-[18] [33] [43]. Few studies in which truckers were recruited from clinics established to treat STIs found much higher prevalence of HIV ranging from 16\% - 57\% [19] [29] [44] [45]. Studies during early 2000 found high prevalence of syphilis (6.3\%) and Hepatitis B (4\% to 6\%) among truckers [32] [43]. Recent studies conducted towards the end of 2000 found relatively lower prevalence of syphilis ranging from $1.7 \%-2.7 \%$ [16] [17]. The prevalence of Neisseria gonorrhea and genital clamydial infections has been found low ranging from $1 \%-2 \%$ in studies conducted during early 2000 [43] or even lesser in more recent research among truckers in India [16] [17].

\subsection{HIV Prevention Programs among Truckers in India}

Efforts to curb the HIV among truckers started in early 1990s in the forms of stand-alone intervention programs primarily in southern and eastern parts of the country with different intervention strategies [46]. Some of the initial efforts during early 1990s were more concentrated on raising awareness through Information, Communication, and Education (IEC) activities and condom promotion [27] [46]-[50]. The communication strategies included group discussion, and distribution of pamphlets [27], using posters, street theatres and puppetry [47] [48] [50], and airing local songs having integrated messages on condom use and road safety [49]. The condom promotion activities included distribution of condoms [48]-[50], providing objects like key chains to keep and carry the condom [49], and advocacy with tea shop owners at trucks' stops to keep condoms [48] [49]. Some interventions used one-to-one and one-to-group education sessions through peers, and counselling to raise awareness about HIV and provided treatment of STIs by setting up clinics with trained medical doctor and supporting staff at selected locations [51]-[54]. Some of these interventions also included FSWs who operate along the highways as participating populations in the intervention [51] [52] [54]. Several strategies such as opening free tea parlors at the STI clinics, and involving people working at places where truckers spend considerable amount of time such as petrol pumps, and Dhaba were also used to increase the outreach activities and motivate truckers for safe sex practices and STI treatment [52] [53] [55] [56].

The HIV prevention efforts among truckers were strengthened towards the end of 1990s. This was the time when a large-scale HIV prevention program among truckers, named as Healthy Highway was initiated [57]. The project was implemented at major halt points where at least 50 trucks were parked at any time of the day or night such as transshipment locations, Dhaba, and check-posts. The Program offered a wide variety of services and activities including STI care and counseling, condom promotion and distribution, dissemination of educational materials, and face-to-face behavioral change communication [57]-[59]. The project trained individuals who come into close contact with truckers, such as petrol attendants, tobacco retailers and tea-shop owners as peer educators to motivate truckers for safe sex practices [58] [59]. The intervention also involved transport companies through advocacy meetings and sensitization efforts for behavioral change among truckers [60]. Operationally, it involved intervention through a network of project partners, including over 30 non-governmental organizations, and 18 transport companies for providing abovementioned project services [58]-[60]. After few years of the start the Healthy Highway program, specific efforts for HIV prevention among truckers were started in 1998 under the second phase of National AIDS Control Program. It established a decentralized mechanism to implement and manage the HIV prevention programs by establishing State AIDS Control Societies in each state for adopting strategies which are most relevant and effective for the local setting [21]. The in- 
terventions for truckers under the National AIDS Control Program were largely based on the strategies of the Healthy Highways program which was handed over to the government in 2000. Although the Health Highway program was envisaged and operated as consolidated national program, it lost its unified national character after being handed over to the government largely because, the central management team of the Healthy Highway program was replaced by independent State AIDS Control Societies [61].

By the end of the 1990s, the key lessons learnt from the various programs for truckers in India were the need to adopt an integrated national approach for programming and management to maintain effectiveness of interventions, selection of intervention sites, and inclusion of transport companies and other stakeholders such as brokers and transport associations [61] [62]. The main challenge realized by the HIV prevention programs among truckers was the unorganized structure of the Indian trucking industry which is fragmented with a vast majority working for small transport operators [63], and lack of coordination among several stand-alone programs being implemented by various State AIDS Control Societies and non-government organizations [61]. The absence of a well-defined and regulated industry architecture limited options for HIV prevention programs for truckers. The road transport sector is regulated by the Motor Vehicles Act 1998 which specifies regulations for truck operators in terms of hours of work of truckers, condition of vehicles, facilities and amenities provided to truckers, etc. [64]. However, enforcement of provisions of the Act is limited to units employing five or more truckers due to which a vast majority of fleet operators do not fall within the ambit of this Act. This makes structural and policy interventions to promote preventive behavior (e.g., requiring that truckers carry condoms, undertake routine health checkups and STI treatment) impractical. Also, the unorganized structure of the industry also implied that workplace interventions were not feasible [61]. Language barriers and absence of a standard network of services also reportedly reduce the efficacy of standalone projects for reaching out to the truckers traveling across the states which often have different languages [61] [65].

Considering these facts about the structure of the industry and learning from previous efforts under HIV prevention programs for truckers, a large-scale HIV prevention program named as Kavach (meaning "shield" in Hindi) among truckers was initiated in 2004 [61]. In addition to working with truckers, this intervention also worked with high-risk groups such as FSWs and their clients, men who have sex with men/transgender and injecting drug users in several Indian states that have high HIV prevalence [65]. The Kavach intervention was initiated at 36 transshipment locations in India covering major national highways along the six routes, namely, North-East, North-West, North-South, West-South, South-East and West-East. The program monitoring data in first 18 months of the project revealed low service utilization by truckers and hence the program was redesigned in 2006 by selecting 17 out of 36 sites through research [61]. The selected intervention sites were the major transshipment locations and check-posts in the country where large number of truckers halt and wait for their consignments for considerable period of time. The redesigned program aimed to provide maximum coverage to truckers by working with high intensity by ensuring more contacts by peer educators, greater program visibility and greater service utilization of project-run clinics. The project-run clinics were named as Khushi, meaning "happiness" in Hindi and Urdu. The redesigned strategy of the intervention was largely influenced by the business franchise model of McDonald. As in McDonald's business model, the look and service of outlets do not differ across any location [66]; the Khushi clinics were branded with uniform appearance and services across all intervention sites to facilitate greater acceptance and easy recognition by truckers.

The Kavach intervention had three components: mid-media events; one-to-group discussions by trained peer educators, and one-to-one counseling and STI care at Khushi clinics by professionals and qualified medical doctors. Mid-media events included street plays, health games, film shows, truckers' festival and the distribution of audio cassettes/compact discs. Films shows were organized to attract truckers and messages on the availability of Khushi clinics were imparted during the movie. Truckers' festivals were large-scale events conducted annually to create an interest among brokers, transporters and truckers and about the program. Audio cassettes/ compact discs with catchy local songs interspersed with spoofs on popular film actors delivering HIV prevention messages and endorsing services at Khushi clinics were distributed to truckers to reinforce positive messages on HIV when they were on the move along the highways. At each intervention site, static and mobile Khushi clinics were established at strategically chosen locations that were accessible to the truckers from that intervention site. These mobile clinics operated either at brokers' premises or in a mobile van. Social marketing of condoms was promoted in partnership with condom marketing organizations by opening non-traditional outlets such as tea stalls, and installing condom vending machines at strategically chosen places at the intervention sites. More details of the Kavach intervention are available elsewhere [61] [65]. The project was handed over to the Nation- 
al AIDS Control Program in March 2012.

Another large-scale intervention which included truckers as one of the targeted populations was implemented during 2002-2006 at 12 port cities in nine states of the country. The project was named as "Operation Lighthouse" and it targeted adult men including truckers, port laborers, and fishermen at selected intervention sites [67]. The heart of this program was the integrated behavior change communications which delivered focused messages around a single behavior change theme across all communication channels for three months at a time. The communication channels were interpersonal communication sessions (one-to-one and one-to-group by trained peer educators), street performances by trained professionals, group games and printed materials. The themes for integrated behavioral change communications were identified through research taking into consideration the exposure, attitudes and behaviors of the targeted populations based on data which were collected each quarter. The intervention established 13 mobile or conveniently-located clinics to provide high-quality voluntary HIV/AIDS counselling and testing services. More information about the intervention could found elsewhere [67] [68].

Besides the large-scale interventions, few attempts have been made to explore new approaches for HIV prevention among truckers. An Information-Motivation-Behavioral (IMB) model-based HIV prevention program was implemented among truckers in 2003 in Chennai, Tamil Nadu [69]. The IMB model asserts that HIV prevention information, motivation, and behavioral skills are the fundamental determinants of HIV preventive behavior [30]. HIV prevention information included facts about how HIV is transmitted and prevented, HIV prevention heuristics, and implicit theories of HIV risk, which hold that one can detect and avoid HIV by assessing a partner's dress, demeanour, and social associations. HIV prevention-motivation included motivation constructs drawn from the Theory of Reasoned Action [70] (e.g., attitudes towards performing specific HIV preventive acts, perceptions of social support for performing HIV preventive acts, and behavioral intentions to engage in HIV preventive acts). The behavioral skills component of the model was composed of an individual's objective ability and perceived self-efficacy for the performance of HIV-preventive behaviors [71]. The IMB intervention consisted of single session of five interactive activities with a group of truckers which took around four hours to complete. These activities were designed to address the specific information, motivation, and behavioral skills deficits that were identified in research previously conducted with truck drivers in India [30] [72]. A total of 9 IMB workshops were implemented with 11 to 16 truckers in each workshop. It was concluded that the IMB interventions had greater effects on condom use with marital partner than its effects on condom use with non-marital partners. More details about the intervention are available elsewhere [69].

Another study conducted among truckers in Andhra Pradesh assessed the association between hygiene, sexual behavior and HIV infection. Participants were recruited into an integrated HIV and hygiene Information-Motivation (IM) program [73]. From 2005 to 2007, a once-a-week workplace intervention was established at a large cargo company's truck depot in Hyderabad, Andhra Pradesh. The intervention incorporated information and motivation theory components from the IMB skills approach to HIV prevention to provide a uniquely integrative HIV and hygiene behavioral intervention. The information component of the intervention included an introduction to germ theory principles, setting the stage for hygiene and HIV transmission teaching. These were discussed within the infectious disease context of communicable disease prevention through sanitary practices. The motivation component of the intervention included individualized counselling on current HIV risk-taking behaviors, potential HIV preventive practices and exploring mechanisms to improve hygiene behaviors. Based on the results from the evaluation studies, it was concluded that while this modest intervention could improve the personal hygiene habits, like hand-washing, it could not alter HIV risk-taking behaviors. More details about the intervention and evaluation are available [73]. More recently, efforts are being made to examine the acceptability of implementing circumcision and pre-exposure prophylaxis as another possible HIV prevention intervention among truckers in the country [74]. The initial results suggest that truckers exhibited low levels of initial commitment towards pre-exposure prophylaxis and even lower for circumcision [74] [75].

\section{Discussion}

This study provides a systematic review of the studies conducted to describe sexual behavior and STI/HIV prevalence as well as efforts to prevent HIV among truckers in India during 1990-2011. This review indicates towards increase in consistent condom use by truckers and decline in STI/ HIV prevalence among them over time in India. However, the HIV prevalence among truckers is still high at slightly above $2 \%$ which is approximately seven times higher than the HIV prevalence among general population $(0.31 \%)$ in the country [76]. Despite sev- 
eral interventions among truckers, about one-fourth of them do not use condoms regularly with FSWs. This proportion reaches to about $60 \%$ when examined for consistent condom use by truckers with non-paid female partners. We also reviewed several interventions with varying strategies and approaches that have been implemented to curb the epidemic among truckers in the country during past two decade. The HIV prevention programs among truckers have improved substantially over time, from initial strategies which were focused primarily to raise awareness to recent interventions which offer a range of services including behavioral change communications, STI/HIV counselling, and STI treatment.

Although, many studies have been conducted to understand the sexual behaviors of truckers, relatively fewer measured the STI/HIV prevalence among them. Considerable variations in the indicators of sexual risk behaviors and STI/HIV prevalence was noticed across studies conducted in different geographic regions of the country within a short interval of time. Although such variations indicate towards the geographic variability in the HIV epidemic among truckers, the comparison across studies is challenged due to differentials in study design, and methods of recruitment. For instance, the STI/HIV prevalence among studies which recruited participants from STI clinics [19] [29] [44] [45] was much higher than that observed among studies which recruited participants from elsewhere, perhaps because of higher likelihood of HIV infections among those who suffer from STIs. Nonetheless, despite such limitations, these were suggestive of truckers' higher vulnerability towards HIV.

Very few studies which relied on large samples confirmed the spatial variations in sexual behaviors and STI/ HIV prevalence among truckers in the country [16] [17] [36]. We also noticed that most of the studies included only the drivers and ignored their helpers despite the fact that the later have been found to have higher vulnerabilities towards HIV [23] [38] [39] [77]. Many studies which included both drivers and helpers provided aggregate level figures and they did not present the findings separately for drivers and helpers [19] [29] [32] [36] [43]. Only few such studies presented selected indicators separately for both drivers and helpers [23] [31]. Since many truckers in India start their carriers as helpers during adolescence [33], the age-group when individuals have tendency to take greater risks than adults [78] and behaviors established during adolescence may continue in early adulthood [79]. Studies are needed to examine the effect of exposure to trucking industry during adolescent on helpers' sexual behaviors and risk of acquiring HIV.

The HIV prevention programs among truckers in the country seem to have evolved based on the learning and evidences from earlier efforts from India and outside. For instance, the recommendations of health highway program [31] [57] [62] and other earlier small-scale interventions [52] [80] coupled with success of franchisee models in reproductive health programs in many parts of the world [81]-[83] led the Kavach program to adopt the business franchise model of McDonald [61]. With availability of more information about correlates of sexual behaviors, STI/HIV prevalence and service utilization, HIV prevention programs attempted to use the evidences for planning and implementation of the interventions [22] [61] [65] [67].

Although there is dearth of studies focusing on rigorous evaluation of large-scale HIV prevention interventions among truckers in India, results from few such efforts are suggestive of success of different programs including the national response to the HIV epidemic among truckers [76], Kavach intervention [17] and Operation Lighthouse program [68]. These studies attempted to evaluate the overall effect of HIV prevention programs on truckers' safe sex practices and prevalence of STI/HIV among them. Studies are needed to examine the impact of different components of the HIV prevention programs to explore what worked and what did not work in the HIV prevention among truckers in India. With increased availability of data and development of sophisticated evaluation methodologies such as propensity score matching methods [84] [85], and mathematical modelling techniques [86], it seems possible to evaluate effects of different components of the HIV prevention programs. Such studies would help the future course of action for the HIV prevention programs among truckers in India and beyond. It is encouraging to observe that efforts to identify innovative approaches such as theory-based intervention programs [69], personal hygiene [73], circumcision [74] [75] and pre-exposure prophylaxis [74] are being examined for their feasibilities to implement acceptability by the community and effectiveness. Such interventions, if found effective, may act as either a new prevention interventions or as adjuncts to current behavioral interventions which would strengthen the HIV prevention programs among truckers in the country.

\section{Acknowledgements}

This paper was written as part of a mentorship programme under the Knowledge Network project of the Population Council, which is a grantee of the Bill \& Melinda Gates Foundation through Avahan, its India AIDS Initiative. 


\section{References}

[1] Chen, X.S., et al. (2006) Prevalence of Sexually Transmitted Infections among Long-Distance Truck Drivers in Tongling, China. International Journal of STD \& AIDS, 17, 304-308. http://dx.doi.org/10.1258/095646206776790141

[2] Atilola, G.O., Akpa, O.M. and Komolafe, I.O. (2010) HIV/AIDS and the Long-Distance Truck Drivers in South-West Nigeria: A Cross-Sectional Survey on the Knowledge, Attitude, Risk Behaviour and Beliefs of Truckers. Journal of Infection and Public Health, 3, 166-178. http://dx.doi.org/10.1016/j.jiph.2010.08.002

[3] Sunmola, A.M. (2005) Sexual Practices, Barriers to Condom Use and Its Consistent Use among Long Distance Truck drivers In Nigeria. AIDS Care: Psychological and Socio-Medical Aspects of AIDS/HI, 17, 208-221. http://dx.doi.org/10.1080/09540120512331325699

[4] Lichtenstein, B., et al. (2008) HIV Risk among Long-Haul Truckers in the USA. Culture, Health \& Sexuality, 10, 43-56. http://dx.doi.org/10.1080/13691050701582936

[5] Lippman, S.A., et al. (2007) Mobility and Its Liminal Context: Exploring Sexual Partnering among Truck Drivers Crossing the Southern Brazilian Border. Social Science \& Medicine, 65, 2464-2473. http://dx.doi.org/10.1016/j.socscimed.2007.07.002

[6] Alam, N., et al. (2007) Sexually Transmitted Infections and Risk Factors among Truck stand Workers in Dhaka, Bangladesh. Sexually Transmitted Diseases, 34, 99-103. http://dx.doi.org/10.1097/01.olq.0000225325.23340.a3

[7] Marck, J. (1999) Long-Distance Truck Drivers' Sexual Cultures and Attempts to Reduce HIV Risk Behaviour amongst Them: A Review of the African and Asian Literature. In: Caldwell, J.C., et al., Eds., Resistances to Behavioural Change to Reduce HIV/AIDS Infection in Predominantly Heterosexual Epidemics in Third World Countries. Health Transition Centre, National Centre for Epidemiology and Population Health, Australian National University, Canberra, 91-100.

[8] Malta, M., et al. (2006) A Qualitative Assessment of Long Distance Truck Drivers' Vulnerability to HIV/AIDS in Itajai, Southern Brazil. AIDS Care, 18, 489-496. http://dx.doi.org/10.1080/09540120500235241

[9] World Bank (2004) Truck Drivers and Casual Sex: An Inquiry into the Potential Spread of HIV/AIDS in the Baltic Region. World Bank, Washington, DC.

[10] Mupemba, K. (1999) The Zimbabwe HIV Prevention Program for Truck Drivers and Commercial Sex Workers: A Behaviour Change intervention., Caldwell, J.C., et al., Eds., Resistances to Behavioural Change to Reduce HIV/AIDS Infection in Predominantly Heterosexual Epidemics in Third World Countries. Health Transition Centre, National Centre for Epidemiology and Population Health, Australian National University, Canberra, 133-137.

[11] Aniebue, P.N. and Aniebue, U.U. (2011) Voluntary Counseling and Willingness to Screen among Nigerian Long Distance Truck Drivers. Nigerian Medical Journal, 52, 49-54.

[12] Bronfman, M., Leyva, R. and Negroni, M.J. (2002) HIV Prevention among Truck Drivers on Mexico’s Southern Border. Culture, Health \& Sexuality, 4. http://dx.doi.org/10.1080/1369105021000041061

[13] Laukamm-Josten, U., et al. (2000) Preventing HIV Infection through Peer Education and Condom Promotion among Truck Drivers and Their Sexual Partners in Tanzania, 1990-1993. AIDS Care, 12, 27-40. http://dx.doi.org/10.1080/09540120047440

[14] National AIDS Control Organization (2006) NACP-III-To Halt and Reverse the HIV Epidemic in India. Ministry of Health \& Family Welfare, Government of India, New Delhi.

[15] Chaturvedi, S., et al. (2006) Sexual Behaviour among Long Distance Truck Drivers. Indian Journal of Community Medicine, 31, 153-156.

[16] Pandey, A., Benara, S.K., Roy, N., Sahu, D., Thomas, M., Joshi, D.K., et al. (2008) Risk Behaviour, Sexually Transmitted Infections and HIV among Long-Distance Truck Drivers: A Cross-Sectional Survey along National Highways in India. AIDS, 22, S81-S90. http://dx.doi.org/10.1097/01.aids.0000343766.00573.15

[17] Pandey, A., Mishra, R.M., Sahu, D., Benara, S.K., Sengupta, U., Paranjape, R.S., et al. (2011) Heading towards the Safer Highways: An Assessment of the Avahan Prevention Programme among Long Distance Truck Drivers in India. BMC Public Health, 11, S15.

[18] Dude, A., Oruganti, G., Kumar, V., Mayer, K.H., Yeldandi, V. and Schneide, J.A. (2009) HIV Infection, Genital Symptoms and Sexual Risk Behavior among Indian Truck Drivers from a Large Transportation Company in South India. Journal of Global Infectious Diseases, 1, 21-28. http://dx.doi.org/10.4103/0974-777X.52977

[19] Manjunath, J.V., Thappa, D.M. and Jaisankar, T.J. (2002) Sexually Transmitted Diseases and Sexual Lifestyles of Long-Distance Truck Drivers: A Clinico-Epidemiologic Study in South India. International Journal of STD \& AIDS, 13, 612-617. http://dx.doi.org/10.1258/09564620260216317

[20] Sanjeev, K., Gang, S.K. and Bajpal, S.K. (2009) A Study of Knowledge, Sexual Behaviour and Practices Regarding HIV/AIDS among Long Distance Truck Drivers. Indian Journal of Public Health, 53, 243-245. 
[21] National AIDS Control Organization (1999) National AIDS Control Programme, Phase II. Ministry of Health and Family Welfare, Government of India, New Delhi.

[22] National AIDS Control Organization (2007) Targeted Intervention for Truckers: Operational Guidelines, NACP III. Ministry of Health \& Family Welfare, Government of India, New Delhi.

[23] Bansal, R.K. (1995) Truck Drivers and Risk of STDs Including HIV. Indian Journal of Community Medicine, 20, 2830.

[24] Rao, K.S., Pilli, R.D., Rao, A.S. and Chalam, P.S. (1999) Sexual Lifestyle of Long Distance Lorry Drivers in India: Questionnaire Survey. BMJ, 318, 162-163. http://dx.doi.org/10.1136/bmj.318.7177.162

[25] Ahmed, S.I. (1997) Truck Drivers as a Vulnerable Group in North East India. In: Aggrawal, O.P., Sharma, A.K. and Indrayan, A., Eds., HIV/AIDS Research in India, National AIDS Control Organization, New Delhi, p. 497.

[26] Singh, Y.N. and Malaviya, A.N. (1994) Long Distance Truck Drivers in India: HIV Infection and Their Possible Role in Disseminating HIV into Rural Areas. International Journal of STD \& AIDS, 5, 137-138.

[27] Singh, Y.N., Singh, K., Joshi, R., Rustagi, G.K. and Malaviya, A.N. (1993) HIV Infection among Long-Distance Truck Drivers in Delhi, India. Journal of Acquired Immune Deficiency Syndromes, 6, 323.

[28] Mishra, R. (1998) STD and HIV/AIDS: A KAP Study among Truck Operators. Health Millions, 224, 11-13.

[29] Thappa, D.M., Singh, S. and Singh, A. (1999) HIV Infection and Sexually Transmitted Diseases in a Referral STD Centre in South India. Sexually Transmitted Infections, 75, 191. http://dx.doi.org/10.1136/sti.75.3.191

[30] Bryan, A.D., Fisher, J.D. and Benziger, T.J. (2001) Determinants of HIV Risk among Indian Truck Drivers. Social Science \& Medicine, 53, 1413-1426.

[31] Department for International Development and Family Health International (2001) Summary Report: Behavioural Surveillance Survey in Healthy Highway Project. Department for International Development and Family Health International, New Delhi.

[32] Bal, B., Ahmed, S.I., Chakraborty, S., Niyogi, S.K., Talukder, A., Chakraborty, N. and Sarkar, K. (2007) HIV Infection among Transport Workers Operating through Siliguri-Guwahati National Highway, India. Journal of the International Association of Providers of AIDS Care (JIAPAC), 6, 56-60. http://dx.doi.org/10.1177/1545109706298405

[33] National Institute of Medical Statistics (2011) Integrated Behavioral and Biological Assessment on National Highways [IBBA-NH]. ICMR, New Delhi.

[34] Churi, C. and Anjenaya, S. (2010) Sexual Behaviour Among Truck Drivers Halting At Kalamboli Truck Terminal, Navi Mumbai. Australasian Medical Journal, 1, 271-274. http://dx.doi.org/10.4066/AMJ.2010.224

[35] Puniya, M.S., Jain, R.B., Punia, A., Dayal, P. and Rana, V. (2010) Assessing HIV/AIDS Awareness and High Risk Behavior among Long Distance Truckers in Northern India. The Internet Journal of Epidemiology, 8, 2.

[36] Transport Corporation of India Foundation (2009) Behaviour Tracking Survey Among Long Distance Truckers: Round 4, August 2009. Transport Corporation of India Foundation, New Delhi.

[37] Zahiruddina, Q.S., Gaidhanea, A.M. Shanbhagb, S. and Zodpeyb, S.P. (2011) High-Risk Sexual Partnerships and Condom Use among Truckers Entering Mumbai City. International Journal of Biological \& Medical Research, 2, 938-941.

[38] Humsafar Trust (2004) A Baseline Understanding of MSM Commercial Sex Activity at Mumbai Truck Terminals. Humsafar Trust, Mumbai.

[39] Mahendra, V.S., et al. (2006) Context and Dynamics of Male-to-Male Sexual Behavior of Truckers in India: Findings from a Multi-Site Qualitative Research Study. Population Council, New Delhi.

[40] Jayadekar, S.S. (1997) HIV Sero-Positivity in Truck Drivers. In: Aggrawal, O.P., Sharma, A.K. and Indrayan, A., Eds., HIV/AIDS Research in India, National AIDS Control Organization, New Delhi, p. 491.

[41] Roy, S., et al. (1997) HIV Seropositivity among The Truck Drivers Plying Through The Eastern Border of Delhi. In: Aggrawal, O.P., Sharma, A.K. and Indrayan, A., Eds., HIV/AIDS Research in India, National AIDS Control Organization, New Delhi, p. 493.

[42] Singh, G.B., Dhaliwal, D.S., Sekhon, A.S., Kaur, K., Singh, S. and Kaur, P. (1999) Seroprevalence of HIV among Truck Drivers. Indian Journal of Community Medicine, 24, 153-157.

[43] Bhoruka Public Welfare Trust (BPWT) (2001) Prevalence of Sexually Transmitted Infections and HIV among Long Distance Intercity Truck Drivers and Helpers of Eastern India. Department for International Development (DFID) and Family Health International (FHI), New Delhi.

[44] Jindal, N., Arora, U. and Singh, K. (2008) Prevalence of Human Immunodeficiency Virus (HIV), Hepatitis B Virus, and Hepatitis C Virus in Three Groups of Populations at High Risk of HIV Infection in Amritsar (Punjab), Northern India. Japanese Journal of Infectious Diseases, 61, 79-81.

[45] Gawande, A.V., Vasudeo, N.D., Zodpey, S.P. and Khandait, D.W. (2000) Sexually Transmitted Infections in Long 
Distance Truck Drivers. Journal of Communication Disorders, 32, 212-215.

[46] Rao, K.S., Jyothi and Gurulakshmi (1999) Intervention Strategies for Reducing HIV Risk Behaviour among Truck Drivers in India, in Resistances to Behavioural Change to Reduce HIV/AIDS Infection in Predominantly Heterosexual Epidemics in Third World Countries. Canberra, April 28-30.

[47] Teddy Trust (1993) An Attempt at Studying the Effectiveness of a Non Governmental Organisation in Promoting AIDS Awareness by the Teddy Trust, Tirumangalam. 9th International AIDS Conference, Berlin, 6-11 June 1993, Abstract No. PO-D33-4302.

[48] Murphy, A. (1996) AIDS Awareness Programme Targeting Truck Drivers and Commercial Sex Workers in Tamil Nadu Using Creative but Low Cost Techniques. 11th International AIDS Conference, Vancouver, 7-12 July 1996, Abstract No. Pub.D.1446.

[49] Raman, S. (1992) Positive Reinforcement to Promote Safer Sex among Clients. AIDS Health Promotion Exchange, PubMed ID 12344819.

[50] The Communication Initiative Network (2003) HIV/AIDS Workplace and Local Community Education Programme, India, 2012.

[51] Louis, A., et al. (1998) Intervention among Truck Drivers \& CSWS along the National Highway 7 at Hosur, Tamil Nadu. International AIDS Confernece, Geneva, 28 June - 3 July1998.

[52] Majumdar, A. (2000) Halting AIDS on Highways. In: Raju, S. and Leonard, A., Eds., Men as Supportive Partners in Reproductive Health: Moving From Rhetoric to Reality, Population Council, New Delhi, p. 38-39.

[53] Ahmed, S.I., et al. (1998) Referral System for STD Management among Truck Drivers along the Highways. 12th International AIDS Conference, Geneva, 28 June - 3 July1998, Abstract No. 23565.

[54] Bhoruka Public Welfare Trust (2004) U Turn. Bhoruka Public Welfare Trust, Kolkata.

[55] Kutikuppala, K.S.R., Mastan, M., Kalavathi, K. and Jaya, N. (2002) Free Tea Parlours (FTPs): A Newer Methodology for Reducing HIV Transmission among Long Distance Lorry Drivers (LDLD). The 16th International AIDS Conference, Barcelona, 7-12 July 2002, Abstract No. MoPeF3948.

[56] Natana, S. (2004) Peer Education Strategy for Attitudinal Change among Truck Drivers. The 15th International AIDS Conference, Bangkok, 11-16 July 2004, Abstract No. C10930.

[57] Singh, K., et al. (2002) Healthy Highways: Reducing HIV/AIDS Risk for Truck Drivers. The 14th International AIDS Conference, Barcelona, 7-12 July 2002, Abstract No. TuPeF5451.

[58] UNAIDS (2001) Working with Men for HIV Prevention and Care. Joint United Nations Programme on HIV/AIDS, Geneva.

[59] World Health Organization (2003) Integrating Gender Into HIV/AIDS Programs: A Review Paper. Department of Gender and Women's Health, Family and Community Health, Geneva.

[60] Singh, J. and Saini, R. (2002) Advocacy Meeting with Transport Company Owners as a Tool for Better STD/HIV Prevention Services. The 14th International AIDS Conference, Barcelona, 7-12 July 2002, Abstract No. TuPeG5569.

[61] Bill \& Melinda Gates Foundation (2008) Off the Beaten Track: Avahan’s Experience in the Business of HIV Prevention among India's Long-Distance Truckers. Bill \& Melinda Gates Foundation, New Delhi.

[62] Mathew, M. (1999) Transport Sector Based Intervention Attempted within the Healthy Highway Project, in Reduction of HIV Vulnerability within the Land Transport Sector: Towards a Public Policy Framework for Addressing HIV/ AIDS in the Transport Sector. UNAIDS, Bangkok.

[63] Asian Institute of Transport Development (1999) Trucking Operations in India. Ministry of Surface Transport, Government of India, New Delhi.

[64] Ministry of Road Transport and Highways (1988) The Motor-Vehicle Act. Government of India, New Delhi. http://morth.nic.in/index2.asp?slid=95\&sublinkid=54\&lang=1:

[65] Bill \& Melinda Gates Foundation (2008) Avahan, the India AIDS Initiative- the Business of HIV Prevention at Scale. Bill \& Melinda Gates Foundation, New Delhi.

[66] Franchise Direct (2012) The Success of the McDonald's Franchise. http://www.franchisedirect.com/information/trendsfacts/thesuccessofmcdonalds/8/1111/

[67] Population Services International (2005) India’s Operation Lighthouse: Breaking the Mold on Traditional HIV/AIDS Behavior Change Approaches. Population Services International, New Delhi.

[68] Population Services International (2006) India (2006): HIV/AIDS TRaC Study among Truck Drivers, Laborers, and Fishermen in Twelve Port Cities: Third Round. Research Division, Population Services International, Mumbai.

[69] Cornman, D.H., Schmiege, S.J., Bryan, A., Benziger, T.J. and Fisher, J.D. (2007) An Information-Motivation-Behavioral Skills (IMB) Model-Based HIV Prevention Intervention for Truck Drivers in India. Social Science \& Medicine, 


\section{4, 1572-1584.}

[70] Fisher, W.A., Fisher, J.D. and Rye, B.J. (1995) Understanding and Promoting AIDS-Preventive Behavior: Insights from the Theory of Reasoned Action. Health Psychology, 14, 255-264. http://dx.doi.org/10.1037/0278-6133.14.3.255

[71] Fisher, J.D. and Fisher, W.A. (2002) The Information-Motivation-Behavioral Skills Model. In: DiClemente, R., Crosby, R. and Kegler, R., Eds., Emerging Promotion Research and Practice, Josey Bass Publishers, San Francisco.

[72] Bryan, A.D., Fisher, J.D. and Benziger, T.J. (2000) HIV Prevention Information, Motivation, Behavioral Skills and Behaviour among Truck Drivers in Chennai, India. AIDS, 14, 756-758. http://dx.doi.org/10.1097/00002030-200004140-00021

[73] Schneider, J.A., Dude, A., Dinaker, M., Kumar, V., Laumann, E.O., Holloway-Beth, A., et al. (2009) General Hygiene, Sexual Risk Behaviour and HIV Prevalence in Truck Drivers from Andhra Pradesh, South India: Implications for Prevention Interventions. International Journal of STD \& AIDS, 20, 39-45. http://dx.doi.org/10.1258/ijsa.2008.008163

[74] Schneider, J.A., Dandona, R., Pasupneti, S., Lakshmi, V., Liao, C., Yeldandi, V., et al. (2010) Initial Commitment to Pre-Exposure Prophylaxis and Circumcision for HIV Prevention amongst Indian Truck Drivers. PLoS ONE, 5, e11922. http://dx.doi.org/10.1371/journal.pone.0011922

[75] Jennit, A., et al. (2008) Awareness and Acceptability of Circumcision among the Long Distance Truck Drivers in Namakkal District of Tamilnadu, India. AIDS 2008, 17th International AIDS Conference, Mexico City, 3 August 2008, Abstract No. CDC0353.

[76] National AIDS Control Organization (2011) Annual Report. Ministry of Health and Family Welfare, Government of India, New Delhi.

[77] Bansal, R.K. (1992) Sexual Behaviour and Substance Use Patterns amongst Adolescent Truck Cleaners and Risk of HIV/AIDS. Indian Journal of Maternal and Child Health, 3, 108-110.

[78] Dickson, N., Paul, C. and Herbison, P. (1993) Adolescents, Sexual Behaviour and Implications for an Epidemic of HIV/AIDS among the Young. Genitourinary Medicine, 69, 133-140.

[79] O’Donnell, B.L., O’Donnell, C.R. and Stueve, A. (2001) Early Sexual Initiation and Subsequent Sex-Related Risks among Urban Minority Youth: The Reach for Health Study. Family Planning Perspectives, 33, 268-275. http://dx.doi.org/10.2307/3030194

[80] Agarwal, A., et al. (1996) Halting AIDS on Highways', A Unique Initiative of Transport Corporation of India-A Transport Business Group in India. Xi International AIDS Conference, Vancouver, 7-12 July 1996.

[81] Montagu, D. (2002) Franchising of Health Services in Low-Income Countries. Health Policy Plan, 17, 121-130. http://dx.doi.org/10.1093/heapol/17.2.121

[82] Ngo, A.D., Alden, D.L., Pham, V. and Phan, H. (2010) The Impact of Social Franchising on the Use of Reproductive Health and Family Planning Services at Public Commune Health Stations in Vietnam. BMC Health Services Research, 10, 54. http://dx.doi.org/10.1186/1472-6963-10-54

[83] Stephenson, R., Tsui, A.O., Sulzbach, S., Bardsley, P., Bekele, G., Giday, T., et al. (2004) Franchising Reproductive Health Services. Health Services Research, 39, 2053-2080. http://dx.doi.org/10.1111/j.1475-6773.2004.00332.x

[84] Rosenbaum, P.R. and Rubin, D.B. (1983) The Central Role of the Propensity Score in Observational Studies for Causal Effects. Biometrika, 70, 41-55. http://dx.doi.org/10.1093/biomet/70.1.41

[85] Rubin, D.B. and Thomas, N. (1996) Matching Using Estimated Propensity Scores: Relating Theory to Practice. Biometrics, 52, 249-264. http://dx.doi.org/10.2307/2533160

[86] Johnson, L.F. and White, P.J. (2011) A Review of Mathematical Models of HIV/AIDS Interventions and Their Implications for Policy. Sexually Transmitted Infections, 87, 629-634. http://dx.doi.org/10.1136/sti.2010.045500 